Article

\title{
Energy potential of long-period oscillations (on the example of Kakhovka plain reservoir, Ukraine)
}

Pavlo V. Anakhov

Department of Infrastructure Systems, National Power Company "Ukrenergo", Kiev, Ukraine, anakhov@i.ua, ORCID ID: 0000-0001-9169-8560

Abstract: The energy potential of long-period oscillations is estimated by comparing it with watercourse power. The relaxation time of long-period waves is chosen for the estimation time interval, during which their amplitude decreases e (Euler's number) times from the initial one. According to calculations, the amount of energy produced during this time by the watercourse is $9.35-18.71$ million $\mathrm{kW} \cdot \mathrm{h}$, while the amount of energy of long-period oscillations is 3-6 times less - 1.60-5.48 million $\mathrm{kW} \cdot \mathrm{h}$. The components of the economic factor of using long-period waves and currents for electricity production are the predictability of their magnitudes and location of maxima, longterm availability, concentration.

Keywords: energy of currents, energy of waves, reservoir, seiche current, seiche wave, storm surge

\section{Nomenclature}

$A \quad$ wave amplitude $(A=h / 2)$

$A_{0} \quad$ initial oscillation amplitude at time $t=0$

$A_{t} \quad$ amplitude at time $t$

$D \quad$ depth of reservoir

$e \quad$ Euler's number

$E_{c} \quad$ amount of energy oscillations of current

$E_{w} \quad$ amount of energy oscillations of waves

$E_{y} \quad$ amount of energy produced by watercourse per year

$g \quad$ gravitational acceleration $\left(g \approx 9.8 \mathrm{~m} / \mathrm{s}^{2}\right)$

$h \quad$ height of wave

$H \quad$ fall of water in the selected area

$k_{r} \quad$ waves and currents availability

$L \quad$ length of reservoir

$l_{w} \quad$ length of wavefront

$M \quad$ wave mode

$P \quad$ watercourse power

$P / m \quad$ specific energy flux per unit width of wavefront and unit wavelength along its propagation direction over one oscillation period
$P / m^{2} \quad$ power density of water flow
$P_{c} \quad$ current power
$P_{w} \quad$ wavefront power
$Q \quad$ water consumption
$s_{c} \quad$ water flow cross-section
$T \quad$ period of wave
$T_{M} \quad$ period of longitudinal seiches in a closed rectangular reservoir with a horizontal bottom
$t_{w c} \quad$ total duration of seiches oscillation sessions over a specified period of time 


$\begin{array}{ll}V & \text { flow velocity } \\ W & \text { width of reservoir } \\ \beta & \text { damping coefficient } \\ \rho & \text { water density }\left(\rho \approx 10^{3} \mathrm{~kg} / \mathrm{m}^{3}\right) \\ \tau & \text { relaxation time } \\ \omega & \text { angular frequency }(\omega=2 \pi / T)\end{array}$

\section{Introduction}

Concerned about the expected shortage of fossil fuels, we continue to look for alternatives for electricity production. Not much time has passed since the opening of the first power plant, a converter of moving water energy into electricity (1878, a small hydroelectric power plant on the Coquet River in England), compared to the history of creative humanity. However, the list of available surface water energy resources has expanded significantly due to the increasing technological capacity to use them (see Fig. 1).

\begin{tabular}{|c|c|c|}
\hline & Energy source & Converter (technology) \\
\hline $\begin{array}{l}\text { Traditional } \\
\text { energy }\end{array}$ & Hydropower & $\begin{array}{l}\text { Hydroelectric Power Plants with capacity from } 20-25 \text { to } 800 \mathrm{MW} \text { (conversion } \\
\text { of kinetic energy of water into electrical energy) }\end{array}$ \\
\hline \multirow{4}{*}{$\begin{array}{c}\text { Alternative } \\
\text { energy }\end{array}$} & \multirow{4}{*}{$\begin{array}{l}\text { Alternative } \\
\text { hydropower }\end{array}$} & 1. Small hydropower. Mini and micro hydropower plants up to $30 \mathrm{MW}$ \\
\hline & & 2. Tidal power plants \\
\hline & & 3. Energy of waves and sea currents \\
\hline & & $\begin{array}{l}\text { 4. Energy of waterfalls (conversion of kinetic energy of water into electrical } \\
\text { energy) }\end{array}$ \\
\hline
\end{tabular}

Fig. 1. Traditional and alternative sources and conversion technologies of hydraulic energy (fragment of figure from

A strong periodicity and a certain height of tidal waves determined the use of tidal energy. The first tidal hydroelectric power plant was built in 1966 at the mouth of the Rance river, France [2].

Wind waves and capillary waves, unlike tides, are good because they occur in any water area. The first wave hydroelectric power plant was opened in 2008 near Aguçadoura, Portugal [2].

Analysis of the wave spectrum of Michigan and Ontario lakes (USA) revealed powerful long-period storm surges and standing waves (seiches) in their composition, which can also be used for electricity production [3, 4].

The purpose of the paper is to evaluate the energy potential of long-period waves and currents of the Kakhovka plain reservoir (Ukraine), the largest of the Dnieper river cascade.

\section{Method}

Estimation of the potential of long-period waves is performed by comparing it with watercourse power [5]:

$$
P=\rho g \bar{Q} H
$$

where $\rho$-water density $\left(\rho \approx 10^{3} \mathrm{~kg} / \mathrm{m}^{3}\right) ; g$ - gravitational acceleration $\left(g \approx 9.8 \mathrm{~m} / \mathrm{s}^{2)} ; \bar{Q}\right.$ - water consumption; $H$ - fall of water in the selected area.

Specific energy flux per unit width of wavefront and unit wavelength along its propagation direction over one oscillation period can be calculated by the formula [3, 4]:

$$
(P / m)=\frac{\rho g^{2} A^{2} T}{64 \pi},
$$

where $A=h / 2, h, T$ - amplitude, height and period of the wave, respectively. 
Seiche period is a function of the morphometric characteristics of the reservoir. The period of longitudinal seiches in a closed rectangular reservoir with a horizontal bottom (see Fig. 2) is calculated by the Merian formula [6]:

$$
T_{M}=\frac{2 L}{M \sqrt{g \bar{D}}}, M=1,2,3 \ldots,
$$

where $M$ - wave mode; $L, D$ - length and depth of the reservoir, respectively.

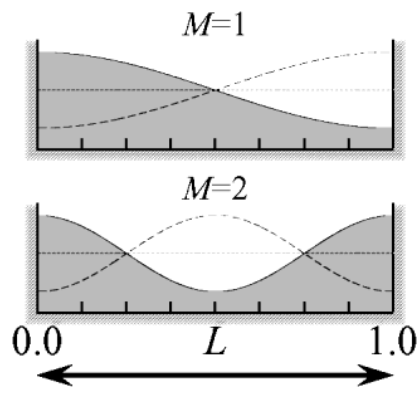

Fig. 2. Profiles of the first two modes of longitudinal seiches in a closed reservoir [6].

The dynamics of the damping seiche is represented by the formula [7]:

$$
A_{t}=A_{0} \cos (\omega t) \exp (-\beta t)
$$

where $A_{t}$ - amplitude at time $t ; A_{0}$ - initial oscillation amplitude at time $t=0 ; \omega$ - angular frequency $(\omega=2 \pi / T)$; $\beta$-damping coefficient. The damping coefficient is inversely proportional to the relaxation time $\tau$, during which the amplitude decreases $e$ times from the initial one.

The wavefront power is calculated by the formula [8]:

$$
P_{w}=(M+1)|P / m| l_{w},
$$

where the specific energy flux is taken under the sign of the module, which takes into account the change in the direction of wave motion relative to the non-excited surface. The wavefront power takes into account its lengths $l_{w}$, which for a rectangular basin is equal to the width of the basin $W$, and the number of which is determined by the wave mode $M$ (see Fig. 2).

Oscillations of seiche waves are accompanied by a reversible current (forward and backward movements of water), as shown in Fig. 3.

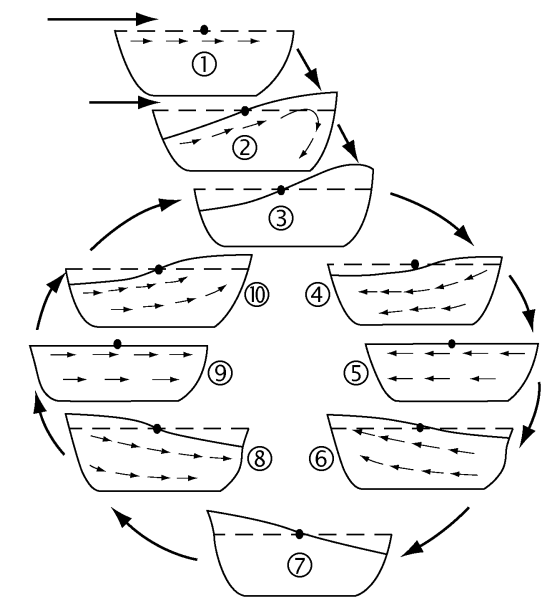

Fig. 3. The sequence of longitudinal profiles of a single-node standing wave excited by the denivelation of the water level in an unstratified reservoir at time $t=0.25 \pi n$, where $n=0,1,2, \ldots$ (from C. Mortimer, quoted by [9])

On the profiles of Fig. 3, the point indicates the wave node, the dashed line indicates the level of the undisturbed water surface; arrows - generalized direction of water mass movement. Seiches are excited by the surge; the arrows above the water surface on the profiles (1), (2) indicate the direction of the wind, which excites the surge. 
The power density of the water flow moving at velocity $V$ can be calculated by the formula [10]:

$$
\left(P / m^{2}\right)=\rho \frac{V^{3}}{2} \text {. }
$$

Let us estimate the velocity of the waves, caused by the seiche current, by the formula [6]:

$$
V=A \sqrt{g / \bar{D}} .
$$

Current power is calculated by the formula [8]:

$$
P_{c}=M\left|P / m^{2}\right| s_{c},
$$

where the flow power density is taken under the module sign. The flow power takes into account the flow cross-sections $s_{c}$, which for a rectangular basin are numerically equal to the product of the width and depth of the basin, and the number of which is determined by the wave mode $M$.

Waves and currents availability for a specified period of time $t$ is calculated by the formula [11]:

$$
k_{r}=\frac{t_{w c}}{t} \times 100 \%
$$

where $t_{w c}$ - total duration of oscillation sessions over a specified period of time.

\section{Results}

Table 1 summarizes the main parameters of the Kakhovka reservoir, as well as the results of calculations of the flow rate of water, falling on the watercourse $(P)$, and the amount of energy produced by the watercourse per year $E_{y}$.

Table 1. Kakhovka reservoir parameters [12]

\begin{tabular}{|r|r|r|r|r|r|r|}
\hline$H, \mathrm{~m}$ & $\bar{Q}, \mathrm{~km}^{3} /$ year & $\bar{D}, \mathrm{~m}$ & $L, \mathrm{~km}$ & $\bar{W}, \mathrm{~km}$ & $P, \mathrm{MW}$ & $E_{y}, \mathrm{mln} \mathrm{kW} \cdot \mathrm{h}$ \\
\hline 16 & 53 & 8.5 & 230 & 9.3 & 260 & 2,276 \\
\hline
\end{tabular}

Large storm surges in the Kakhovka reservoir, the largest in the Dnieper cascade, are formed, first of all, in its wide shallow northeast part. At the Plavni post located here, on March 15, 1966, a $99 \mathrm{~cm}$ surge was recorded; on January 5, 1969, a $106 \mathrm{~cm}$ surge was observed. Significant (up to 80-90 cm) surge phenomena occur at the Nova Kakhovka post. On January 5, 1969, at a wind speed of up to $30 \mathrm{~m} / \mathrm{s}$, the surge there reached $83 \mathrm{~cm}$, while the water level at the Plavni post decreased by $102 \mathrm{~cm}$ east wind. A significant surge $(87 \mathrm{~cm})$ was recorded there on November 11,2007 [12].

The excitement of seiches by the storm surge is shown in Fig. 4, the standing wave profiles, as suggested by M. Longuet-Higgins [13], are represented by the corresponding vibrational positions of the mathematical pendulum.

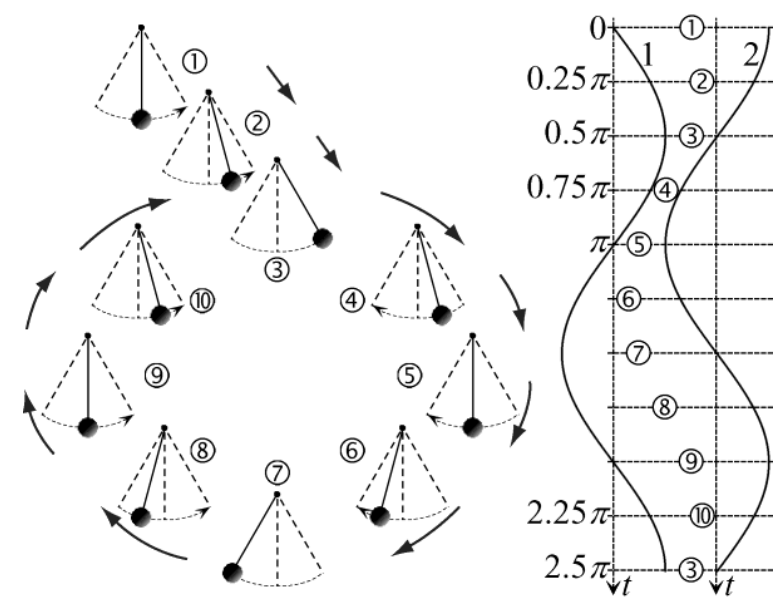

Fig. 4. Standing wave oscillations: on the left - mathematical pendulum whose positions correspond to the standing wave profiles in Fig. 3; on the right - water levels in the anti-node (1) and the flow velocity in the node (2), at fixed times $t=0.25 \pi n, n=0,1,2, \ldots$ 
Table 2 presents statistics of observations of seiche water oscillations in the Kakhovka reservoir.

Table 2. Number and total duration of seiche oscillations in the central part of the Kakhovka reservoir during the summer months of 1970 and 1971 [7]

\begin{tabular}{|c|r|r|r|r|r|r|}
\hline \multirow{2}{*}{ Observed periods, $\mathrm{h}$} & \multicolumn{4}{|c|}{1970} & \multicolumn{3}{|c|}{1971} \\
\cline { 2 - 7 } & Number of oscillations & Duration, $h$ & $k_{r}, \%$ & Number of oscillations & Duration, $h$ & $k_{r}, \%$ \\
\hline $9.0-14.5$ & 13 & 156 & 7.07 & 12 & 144 & 6.52 \\
\hline $5.0-8.5$ & 37 & 251 & 11.37 & 67 & 456 & 20.65 \\
\hline $2.8-4.9$ & 129 & 504 & 22.83 & 164 & 640 & 28.99 \\
\hline $2.0-2.7$ & 14 & 33 & 1.49 & 11 & 26 & 1.18 \\
\hline $1.0-1.9$ & 21 & 31 & 1.40 & 42 & 63 & 2.85 \\
\hline
\end{tabular}

The dynamics of the seiche power of the Kakhovka reservoir during the oscillation relaxation time is shown in Fig. 5.

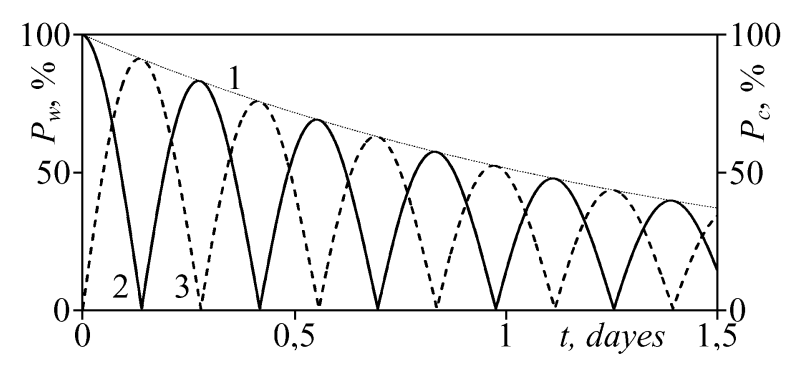

Fig. 5. Instant power dynamics of the damping single-node seiche of the Kakhovka reservoir: 1 - envelope; 2 - wave power variations; 3 - current power variations

The wave and current phases correspond to the oscillation profiles of Fig. 4. The authors of the papers [3, 4], considering the surge energy on the Great Lakes (USA, Canada), examine extreme cases. Using their idea, let us consider the energy of long-period oscillations of the Kakhovka reservoir for a $106 \mathrm{~cm}$ surge (see Table 3).

Table 3. Calculated powers $P_{w}, P_{c}$ and amounts of energy oscillations of waves and current $E_{w}, E_{c}$, produced during the relaxation time, with the amplitude of seiche oscillations, excited by a $106 \mathrm{~cm}$ surge on January 5,1969 .

\begin{tabular}{|c|c|c|c|c|c|c|c|}
\hline$M$ & $\begin{array}{l}\text { Period under field conditions } \\
\text { [7] }\end{array}$ & $\tau$, days [7] & $\beta, \mathrm{s}^{-1}$ & $P_{w}, \mathrm{MW}$ & $\begin{array}{l}E_{w}, \mathrm{mln} \\
\mathrm{kW} \cdot \mathrm{h}\end{array}$ & $\begin{array}{l}P_{c}, \\
\text { MW }\end{array}$ & $\begin{array}{l}E_{c}, \\
\mathrm{~kW} \cdot \mathrm{h}\end{array}$ \\
\hline \multirow[t]{2}{*}{1} & \multirow[t]{2}{*}{13 h 24 min. } & 1.5 & $7.716 \times 10^{-6}$ & $5.76 \times 10^{6}$ & 1.60 & 135 & 38 \\
\hline & & 2 & $5.787 \times 10^{-6}$ & $8.62 \times 10^{6}$ & 2.39 & 197 & 55 \\
\hline \multirow[t]{2}{*}{2} & \multirow[t]{2}{*}{$7 \mathrm{~h} 18 \mathrm{~min}}$. & 2 & $5.787 \times 10^{-6}$ & $13.12 \times 10^{6}$ & 3.64 & 748 & 208 \\
\hline & & 3 & $3.858 \times 10^{-6}$ & $19.73 \times 10^{6}$ & 5.48 & 1149 & 319 \\
\hline
\end{tabular}

\section{Conclusions}

1. Calculations showed the significant energy potential of the "storm surge - seiche wave and current" sequence. The amount of energy produced by the watercourse for 1.5-3 days is 9.35-18.71 million $\mathrm{kW} \cdot \mathrm{h}$, compared with the amount of energy produced by long-period waves and currents (1.60-5.48 million $\mathrm{kW} \cdot \mathrm{h})$.

2. Predictability of wave values, wave availability, location of maxima (see Table 4) are components of the economic factor of using them for electricity production.

3. The energies of waves and currents are distributed over the reservoir area, while the energy of falling water is concentrated in a relatively narrow line of the dam. To concentrate the energy of long-period waves, the authors of the papers $[3,4]$ suggest using tidal basins. 
Table 4. Typical features of seiche oscillations.

\begin{tabular}{|l|l|}
\hline 1. Value & $\begin{array}{l}\text { Seiche oscillations are a common condition for any reservoir at any time of its existence, and if not } \\
\text { always noticeable, it is only a consequence of the small, in most cases, oscillation amplitudes. For } \\
\text { example, the height of the seiches observed in the Kakhovka reservoir is 0.02-0.1 m [14]. }\end{array}$ \\
\hline $\begin{array}{l}\text { 2. Availability } \\
\text { 3. Location of } \\
\text { maxima }\end{array}$ & $\begin{array}{l}\text { The energies of waves and currents are unevenly distributed over the reservoir area, which allows } \\
\text { average observed number of extreme seiche exciting waves is } 8 \text { units per month [3]. }\end{array}$ \\
\hline
\end{tabular}

4. The power $P_{w}$ and the amount of energy produced by seiche waves $E_{w}$ greatly exceed the power $P_{c}$ and the amount of energy produced by the seiche current $E_{c}$. In our case, it is 4-5 orders of magnitude.

\section{References}

1. Naraevs'kyj, S. V. Competitiveness of alternative energy technologies; Publisher: National Technical University of Ukraine "Igor Sikorsky Kyiv Polytechnic Institute", Kyiv, Ukraine, 2015 (in Ukrainian).

2. Curto, D.; Franzitta, V.; Guercio, A. Sea Wave Energy. A Review of the Current Technologies and Perspectives, Energies 2021, Volume 14, 6604.

3. Sogut, D. V.; Farhadzadeh, A.; Jensen, R. E. Characterizing the Great Lakes marine renewable energy resources: Lake Michigan surge and wave characteristics, Energy 2018, Volume 150, pp. 781-796.

4. Sogut, D. V.; Jensen, R. E.; Farhadzadeh, A. Characterizing Lake Ontario Marine Renewable Energy Resources, Mar. Technol. Soc. J. 2019, Volume 53, pp. 21-37.

5. De Rosa, P.; Fredduzzi, A.; Cencetti, C. Stream Power Determination in GIS: An Index to Evaluate the Most 'Sensitive' Points of a River, Water 2019, Volume 11, 1145.

6. Rabinovich, A. B. Seiches and Harbor Oscillations. In Handbook of Coastal and Ocean Engineering, Editor Kim, Y. C.; Publisher: World Scientific Publ., Singapoure, 2009; pp. 193-236.

7. Sudol'skij, A. S. Dynamic phenomena in water bodies. Publisher: Hydrometeoizdat, Leningrad, Russia, 1991 (in Russian).

8. Anakhov, P. V. Integrated use of standing waves of reservoirs. Hydropower of Ukraine 2018, No. 1-2, pp. 49-51 (in Ukrainian).

9. Boegman, L. Currents in Stratified Water Bodies 2: Internal Waves. In Encyclopedia of Inland Waters, Volume 1; Editor Likens, Gene E; Publisher: Elsevier, Oxford, 2009; pp. 539-558.

10. Novico, F.; Sudjono, E. H.; Egon, A.; Menier, D.; Methew, M.; Pratama, M. B. Tidal Current Energy Resources Assessment in the Patinti Strait, Indonesia, IJRED 2021, Volume 10, pp. 517-525.

11. Aderinto, T.; Li, H. Review on Power Performance and Efficiency of Wave Energy Converters, Energies 2019, Volume 12, 4329.

12. Vyshnjevs'kyj, V. I. The Dnieper River. Publisher: Interpres Ltd, Kiev, Ukraine, 2011 (in Ukrainian).

13. Longuet-Higgins, M. S. Can Sea Waves Cause Microseisms? In Symposium on Microseisms, , 4-6 September 1952, Harriman, N.Y., pp. 74-86.

14. Labzovskij, N. A. Non-periodic sea level fluctuations. Publisher: Hydrometeoizdat, Leningrad, USSR, 1971 (in Russian). 